\title{
Werner 症候群の一家系における遺伝子解析
}

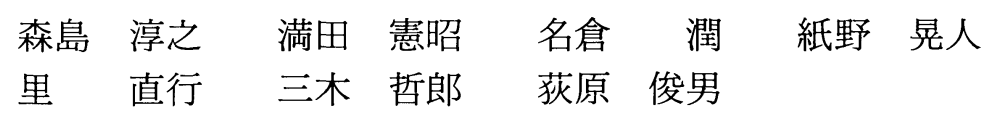

\begin{abstract}
<要 約 > Werner 症候群 (WRN) は, 常染色体性劣性の遺伝性早老症であり, 原因遺伝子座位は第 8 染色体短腕に存在することが知られているが, 原因遺伝子そのものは未だ単離同定されていない. 本 邦での有病率は約 20 万人に 1 人で, 発症頻度が白人集団に比べて高い疾患の一つである. 今回, 甲状腺 乳頭状腺癌と骨髄異形成症候群を合併し，39歳にて死亡した患者の 3 人の同胞（当患者を含めて 2 人が 発症）と，イトコ婚である両親に対して遺伝子解析を行った。

WRN 領域に存在する 4 種のマイクロサテライト多型，D8S360，D8S1055，D8S339，ANK1を用いて 遺伝子型を決定し，ハプロタイプを作成した。患者の同胞のうち長女と次女の 2 人は，臨床診断では健 常者である. 長女は正常のハプロタイプを受け継いでいたが, 次女はWRN 変異遺伝子をもつハプロタ イプを受け継いでいた.しかし,この 2 人は臨床的に異常はなかった。この結果は, WRN が劣性遺伝で あることを裏付けた。

本症候群の発症機序は，未だ不明であるが，老化の機序を探る手立てとして有力視されており，将来 単離同定されるであろう WRN 遺伝子の機能を解明すれば, 老化機序解明の糸口になると考えられる.
\end{abstract}

Key words : Werner 症候群, マイクロサテライト多型, 遺伝子診断, ホモ接合性マッピング

\section{緒言}

Werner 症候群 (以下 WRN と略す) は, 常染色体性 劣性の遺伝性早老症であるが，その原因遺伝子は未だ 単離同定されていない. 本邦での有病率は20万人に 1 人で，白人集団に比べ発症頻度の高い疾患の一つであ る. 患者は, 20 歳代上り, 白内障, 性腺機能低下, 皮 膚の角化などの老化症状で発症し，50歳前後に間葉系 の悪性腫瘍や動脈硬化による虚血性心疾患が原因で死 亡する. 細胞生物学的には, 血小板由来増殖因子 (PDGF), 線維芽細胞増殖因子（FGF）に対する增殖 反応性の低下 ${ }^{1}$ が報告されている。皮膚線維芽細胞を 用いた研究では, 細胞の継代寿命が短く ${ }^{2)}$, 自然突然変

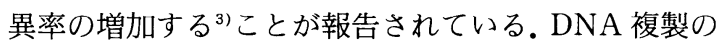
遅延, 複製単位の減少が認められるため, DNA 複製過 程の異常によって発症する可能性が高(4). 以上の細 胞生物学的特徴を手がかりとして, 原因遺伝子の単離 同定が試みられたが，今のところ成功していない，最 近のヒト・ゲノム解析研究の一手法であるポジショナ

A. Morishima, N. Mitsuda, J. Nakura, K. Kamino, N. Sato, T. Miki, T. Ogihara : 大阪大学医学部老 年病医学講座

受付日：1995.7.25, 採用日：1995。10.24
ルクローニングにより, 原因遺伝子座位の第 8 染色体 短腕へのマッピング, さらに原因遺伝子そのものの単 離も可能となってきている ${ }^{5 / 6)}$. 将来, 単離同定される であろう WRN 遺伝子の機能の解明は, 老化機序解明 の糸口となると考えられる. 今回, 染色体顕微切断法 (microdissection) で独自に単離したマイクロサテラ イト多型の 1 種 (D8S1055) と, 既報告のマイクロサテ ライト多型の 3 種 (D8S360, D8S339, ANK1) を使っ て近親婚家系の遺伝子型を決定し, ハプロタイプを作 成し保因者診断を行った。

\section{対象及び方法}

\section{家系}

患者：39歳，女性

主訴：左眼球突出

既往歷：特記すべき事なし

家族歴 (図 1 参照)：両親がイトコ婚. II-3 (三女) が発端者で，II-4（四女）もWRN 患者である。両親 （I -1，I -2), 長女（II-1）と次女（II-2）は臨床的に は, 全く健常者である.

現病歴：27歳頃より, 左足底䳕眼を認め, 左下根痛 が出現するが放置していた。31歳時, 歩行困難を主訴 に当院皮膚科を受診し,精査の結果, WRN と診断され 


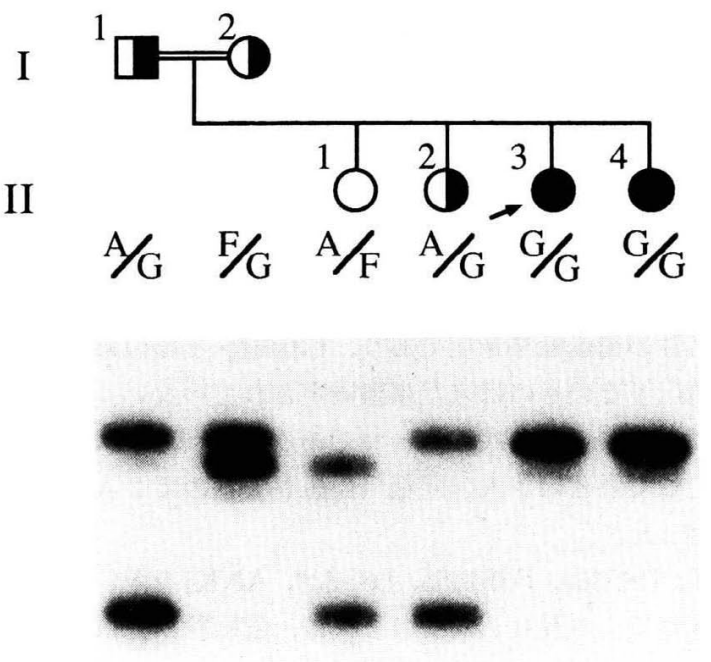

図 1 発端者の家系の構成員について, D8S339を利用 して決定した遺伝子型.

た.内科的精查を目的として，当科共観となったが， 前頭骨と肺への転移を伴う甲状腺乳頭状腺癌を発見さ れた。脳神経外科にて前頭骨切除術施行し，次に第二 外科にて甲状腺全摘術施行した. 以後, 年 1 回の割合 で, 残存する肺に転移した甲状腺乳頭状腺癌に対し, アイソトープ治療 ( ${ }^{131}$ I $\left.100 \mathrm{mCi}\right)$ を行った。平成 4 年 10月 (39歳時), 左眼痛と眼球突出をきたし, 頭部 CT にて, 左眼窩に骨融解を伴う陰影を䜑めたため, 甲状 腺乳頭状腺癌の眼窩への転移であると診断した。同年 12月, 同量の ${ }^{131} I$ 治療を行い, 外科的処置施行目的に て入院となった。平成 5 年 1 月, 当院脳神経外科にて, 左眼窝形成術を行った。術後より，末血に招ける汎血 球減少をみとめ, G-CSF を用いて経過観察するが，血 液像の悪化を認め，末梢血に骨髄芽球が出現するよう になり, 骨髄穿刺, 白血球の染色体検査より, 骨髄異 形成症候群と診断した。その後も骨髄芽球の増加が続 き, 同年 6 月の時点で骨髄芽球の割合が全白血球の $50 \%$ を越之，急性骨髄性白血病へ移行した。同年 8 月, 左下肺野へ転移した甲状腺癌による肺炎により死亡し た.

入院時現症：身長 $147.5 \mathrm{~cm}$, 体重 $46.0 \mathrm{~kg}$, 血压 $130 /$ $80 \mathrm{mmHg}$, 上下肢左右差なし, 脈拍 $80 /$ 分, 体温 $35.5^{\circ} \mathrm{C}$, 鳥様顔貌, 頭髪に白髪が混じる. 両眼とも白内障手術 後. 皮膚は萎縮乾燥. 高調な声. 腱反射正常. 両足底 に鵎眼あり。下腿潰湢は認めない, 厚生省の班会議作
成の WRN の診断基準 ${ }^{7}$ のうち，3 主徴候，5副徴候を 示した。

\section{遗伝子解析}

4 種のマイクロサテライト多型, D8S $360^{8)}$, D8 $\mathrm{S} 1055^{9)}, \mathrm{D} 8 \mathrm{~S} 339^{10)}, \mathrm{ANK} 1^{11}$ を用いて, 家系構成員の 遺伝子型を決定した，表 1 に，各マイクロサテライト 多型の対立遗伝子の長さと遺伝子頻度を示す。各遺伝 子の遺伝子地図での順序は，第 8 染色体短腕末端から 動原体へ順に，D8S360-D8S1055-D8S339-ANK1とな る. 各マイクロサテライト多型のプライマーの塩基配 列, アニーリングの温度, PCR 産物の長さは既に報告

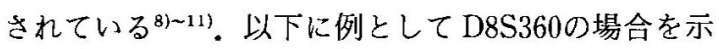
す.フォワードプライマーの塩基配列は $5^{\prime}$ CTAGCTCCTGTGTTTCCATCA-3', リバースプラ イマーの塩基配列は5'-TCTCACAGGTGCC. TGTGCAG-3'で,それぞれのプライマーを合成した. フォワードのプライマーを RI 標識し, $96^{\circ} \mathrm{C} 45$ 秒の denature 反忍, $60^{\circ} \mathrm{C} 30$ 秒の annealing 反応, $72^{\circ} \mathrm{C} 30$ 秒の extension 反応を 1 サイクルとし, 35サイクルの PCR を行った. 日本人健常者50名を解析すると $101 \mathrm{bp}$ から2 bp 間隔で $115 b p$ まで 8 個の対立遺伝子が 8 種存在し, 観察されたへテロ接合性は78\%であった ${ }^{81}$.

\section{結 果}

図 1 に解析した結果を示す，父（I-1）は A/Gのへ

表 1 各マイクロサテライト多型の対立遺伝子の長さ と遺伝子頻度

\begin{tabular}{c|r|r|r|r|r|r|r|r}
\hline \multirow{2}{*}{\begin{tabular}{c|r|r|r|r|} 
対立 \\
遺伝子
\end{tabular}} & \multicolumn{2}{|c|}{ D8S360 } & \multicolumn{2}{c|}{ D8S1055 } & \multicolumn{2}{c|}{ D8S339 } & \multicolumn{2}{c}{ ANK1 } \\
\cline { 2 - 8 } & 長さ & 頻度 & 長さ & 頻度 & 長さ & 頻度 & 長さ & 頻度 \\
\hline A & 101 & 0.15 & 95 & 0.01 & 163 & 0.32 & 107 & 0.44 \\
B & 103 & 0.01 & 97 & 0.02 & 165 & 0.05 & 109 & 0.00 \\
C & 105 & 0.23 & 99 & 0.22 & 167 & 0.00 & 111 & 0.04 \\
D & 107 & 0.34 & 101 & 0.04 & 169 & 0.00 & 113 & 0.5 \\
E & 109 & 0.12 & 103 & 0.00 & 171 & 0.00 & 115 & 0.02 \\
F & 111 & 0.05 & 105 & 0.02 & 173 & 0.37 & & \\
G & 113 & 0.09 & 107 & 0.01 & 175 & 0.13 & & \\
H & 115 & 0.01 & 109 & 0.36 & 177 & 0.09 & & \\
I & & & 111 & 0.07 & 179 & 0.01 & & \\
J & & & 113 & 0.01 & 181 & 0.03 & & \\
K & & & 115 & 0.06 & & & & \\
L & & & 117 & 0.07 & & & & \\
M & & & 119 & 0.02 & & & & \\
N & & & 121 & 0.03 & & & & \\
O & & & 123 & 0.04 & & & & \\
P & & & 125 & 0.02 & & & & \\
\hline
\end{tabular}




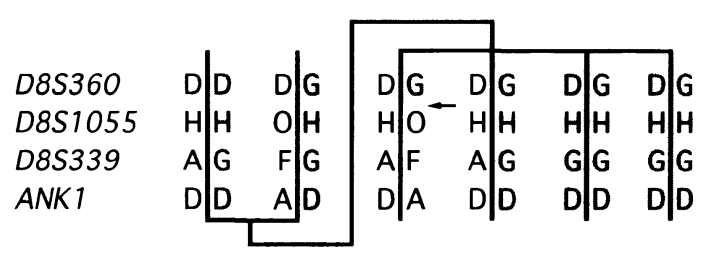

図 24 種のマイクロサテライト多型を利用して作製 したハプロタイプを示す。網目模様の部分はWRN 変異遺伝子をもつハプロタイプ，矢印は染色体上で 遺伝子の組換えが発生したと考えられる位置を示 す.

テロ接合体, 母( I -2) は F/G のへテロ接合体で, WRN 患者である三女（II-3）と四女（II-4）は，G/Gのホモ 接合体であった。長女（II-1）は $\mathrm{A} / \mathrm{F}$ ，次女（II-2）は $\mathrm{A} / \mathrm{G}$ のへテロ接合体であった。他の 3 種のマイクロサ テライト多型の解析結果をまとめてハプロタイプを作 成した結果を図 2 に示す。図の網目模様の部分は WRN 変異遺伝子をもつハプロタイプを示す。矢印は 染色体上で遺伝子の組換えが発生したと考えられる位 置を示す。父（Ｉ－1）が D-H-G-D の変異 WRN 遺伝子 を含む染色体を受け継ぎ，母（I -2）は G-H-G-D の変 異染色体を受け継いでいた，長女（II-1）は，D8S360 とD8S1055との間で遺伝子組換えを発生したと考え られる.I-1とI-2も, 以前に同じマーカー間で組換え の起こったと思われる異なる変異染色体が受け継がれ ており，両マーカー間の遺伝子距離は近くないことが 分かる。次女（II-2）は，G-H-G-Dのハプロタイプを 母より受け継いでいるため, WRN 変異遺伝子を 1 個 もつ保因者であることが判明した。三女 (II-3) と四女 （II-4）は，両親より変異 WRN 遺伝子をもつ染色体 D-H-G-D/G-H-G-D を受け継いだため，WRN が疾患 として発症したと考えられる.II-1とII-2は, WRN 変 異遺伝子を全くもたない姉と, 変異遺伝子をへテロ接 合体で持つ妹であるが，臨床的には両者に異常はなく 健常者であった。この結果は, WRN は劣性遺伝である ことを裏付けた。

\section{考察}

WRN は, 悪性黒色腫, 髄膜腫など, 間葉系の特殊な 悪性腫瘍を高頻度に合併することが知られている．今 回，甲状腺乳頭状腺癌と骨髄異形成症候群を合併した WRN の患者を経験したが，WRN における多重癌の 合併の報告は稀ではない ${ }^{12}$. 本患者においても, 骨髄異 形成症候群発症後, 約半年で急性骨髄性白血病への移
行を認めており, 基礎疾患としての WRN の存在が注 目される ${ }^{13)}$. 本症候群の発症機序は，末だ不明である が, 老化の機序を探る手立てとして有力視されており, 原因遺伝子の単離同定後の研究を待つことになる。本 症例においても，染色体の欠失などの異常を認めてお り, 遺伝子修復過程や複製過程に異常がある可能性が 示唆される.

多型性遺伝子マーカーとしての DNA マーカーは, RFLP P VNTR から，(CA) 反復配列などからなるマ イクロサテライト多型を利用する時代になり, WRN 遺伝子のマッピングもこれらを利用して行われ $た^{14) \sim 17)}$.マイクロサテライト多型は全染色体にほぼ均 等に分布し，へテロ接合体となる頻度が高いため連鎖 分析に役立ち, 少量の高分子量 DNA で解析が可能で あるため非常に有用な遺伝子マーカーである。既に， 全染色体上で 3,000 個以上単離され, 米国の私企業より 市販もされており, 全世界の研究室で, 遺伝子地図作 成や遺伝子診断に利用されている ${ }^{18)}$. 今回, WRN 家系 の遺伝子型を決めることにより, WRN の正確な遺伝 子座位の決定と保因者診断が可能であることを示し た. 将来単離同定される WRN 遺伝子を利用すれば, さらに正確な遺伝子診断が可能となるであろう。

今回のハプロタイプの解析によって, 長女 ( I -2) は, WRN 原因遺伝子を受け継いでいないが，次女（II -2) は，WRN 原因遺伝子をへテロ接合体でもつことが判 明した. 八プロタイプの解析は，遺伝子診断の精度を 向上させる。一般に，原因遺伝子領域（D8S1055-D8 S339）を挟んだ二つの遺伝子マーカー（染色体末端側 の D8S360と動源体側の ANK1）を利用した遺伝子診 断は精度が高い事が知られている。今回の場合を例に とると, 次女の G-H-G-D ハプロタイプが正常の WRN 遺伝子を含んでいるためには，8S360と D8S1055-D8 S339領域の間と, D8S1055-D8S339領域とANK1の間 で二度遺伝子組み換えの発生する必要があるが，この 頻度は極めて低い $(\mathrm{p}<0.001)$ 。このように，4つの遺 伝子マーカーを用いた遺伝子診断の精度は高いと考え られる。

ホモ接合型マッピングは, 発生頻度が稀な常染色体 性劣性遺伝病で, 近親婚患者が多い他の疾患に応用で きる。例えば，最近日本人によって発見された福山型 先天性筋ジストロフィー症座位がホモ接合型マッピン グにより決定されている ${ }^{19)}$. WRN のように日本人に 関連のある疾患の解析は, 積極的に研究を推進させる 必要があると考える。 
最後に, これまでの, 分子遺伝学的解析から, 日本 人の WRN の遺伝子は, $8 \mathrm{p} 11.2$ 付近の一カ所に存在 し，遺伝子座位の遺伝的多型性はないと考えられる。 WRN 遺伝子近傍のハプロタイプの解析から, 少なく とも 5 つの独立した遺伝子変異が日本人集団に存在す ることが判明している ${ }^{20211}$. 数年以内に単離同定され るWRN 遺伝子の機能は, 老化機構を考える大きな手 がかりとなるであろう。

\section{文献}

1) Bauer EA, Silverman N, Busiek DF, Kronberger $\mathrm{A}$, Deuel TF: Diminished response of Werner's syndrome fibroblasts to growthfactors PDGF and FGF. Science $1986 ; 234: 1240-1243$.

2) Salk D, Bryant E, Au K, Hoehn H, Martin GM : Systematic growth studies, cocultivation, and cell hybridization studies of Werner syndrome cultured skin fibroblasts. Hum Genet 1981; 58 : $310-316$.

3) Fukuchi K, Martin GM, Monnat RJ Jr : Mutator phenotype of Werner syndrome is characterized by extensive deletions. Proc Nat Acad Sci $1989 ; 86$ : 5893-5897.

4) Epstein C, Martin G, Schultz AL, Motulsky AG : Werner's syndrome: A review of its symptomatology, natural history, apthologic features, genetics and relationship to the natural aging process. Medicine $1986 ; 45: 177-211$.

5）三木哲郎, 名倉 潤, 紙野晃人, 荻原俊男：早老症 一ウェルナー症候群と Hutchinson-Gilford プロ ジェリア症候群一, Molecular Medicine「老化と 神経性疾患」. $1993 ; 30 ： 1166-1173$.

6）名倉 潤, 三木哲郎, 荻原俊男：遺伝性早老症とウ エルナー症候群. Biomedica 1993；8：11541158.

7）尾形悦郎：総括研究報告. 厚生省特定疾患ホルモ ン受容体機構異常調查研究班, 昭和59年度総括研 究事業報告書, p13-27, 1984.

8) Kamino K, Nakura J, Kihara K, Ye L, Nagano $\mathrm{K}$, Ohta $\mathrm{T}$, Jinno $\mathrm{Y}$, Niikawa $\mathrm{N}$, Miki $\mathrm{T}$, Ogihara $\mathrm{T}$ : Population variation in the dinucleotide repeat polymorphism at the D8S360 locus. Hum Mol Genet 1993; $2: 1751$.

9) Ye L, Kihara K, Nakura J, Kamino K, Mitsuda N, Takahashi-Fujii A, et al: Dinusleotide repeat polyumorphism at the $\mathrm{D} 8 \mathrm{~S} 1055$. Jpn J
Hum Genet $1994 ; 39$ : 441-443.

10) Thomas $W$, Drayna D: A polymorphic dinucleotide repeat at the D8S339 locus. Hum Mol Genet $1993 ; 2: 828$.

11) Polymeropoulos MH, Rath DS, Xiao H, et al: Dinucleotide repeat polymorphism at the human ankyrin gene (ANK1). Nucleic Acids Res $1991 ; 19: 969$.

12）大野賢朗, 富田勝朗郎, 土屋弘行, 松原藤継, 稲沖 真, 川島篤弘. 悪性腫瘍を合併した Werner 症候群 の 3 例. 整形・災害外科 $1990 ; 33: 1293-1298$.

13) Takemoto $Y$, Hata $T$, Kamino K, Mitsuda N, Miki T, Kawagoe H, et al: Leukemia Developing after ${ }^{131} \mathrm{I}$ Treatment for Thyroid Cancer in a Patient with Werner's syndrome: Molecular and Cytogenic Studies. Internal Med 1995; $34: 863-867$.

14) Goto M, Rubenstein M, Weber J, Woods K, Drayna D: Genetic linkage of Werner's syndrome to five markers on chromosome 8 . Nature $1992 ; 355:$ 735-737.

15) Schellenberg GD, Martin GM, Wijsman EM, Nakura J, Miki T, Ogihara: Homozygosity mapping and Werner's syndrome. Lancet 1992; 339: 1002 .

16) Nakura J, Miki $T$, Nagano $K$, Kihara $K$, Ye L, Kamino K, et al: Close linkage of the gene for Werner's syndrome to ANK1 and D8S87 on the short arm of chromosome 8. Gerontrol 1993; $39: 11-15$.

17) Nagano K, Nakura J, Kihara K, Ye L, Kamino $\mathrm{K}$, Mitsuda $\mathrm{N}$, et al: Isolation and mapping of microsatellites from a library microdissected from the Werner's syndrome region, 8p11.2-p22. Jpn J Hum Genet 1993 ; 38 : 393-399.

18) Gyapay G, Morissette J, Vignal A, Dib C, Fizames C, Millasseau P, Marc S, et al: The 1993-94 Genethon human genetic linkage map. Nature Genet 1994 ; 7 : 246-339.

19) Toda T, Segawa M, Nomura $Y$, Nonaka I, Masuda K, Ishihara T, et al : Localization of a gene for Fukuyama type congenital muscular dystrophy to chromosome 9q31-33. Nature Genet $1993 ; 5$ : 283-286.

20) Ye L, Nakura J, Mitsuda N, Fujioka Y, Kamino $\mathrm{K}$, Ohta $\mathrm{T}$, et al: Genetic association between 
chromosome 8 microsatellite (MS8-134) and Werner syndrome (WRN): Chromosome microdissection and homozygosity mapping. Genomics $1995 ; 28: 566-569$.

21) Yu C-E, Oshima J, Goddard KAB, Miki T,
Nakura J, Ogihara T, et al : Linkage disequilibrium and haplotype studies of chromosome $8 \mathrm{p}$ 11.1-21.1 markers and Werner's syndrome. Am J Hum Genet 1994 ; 55 : 356-364.

Abstract

\title{
Genetic Analysis of Werner Syndrome in a Family
}

\author{
Atsuyuki Morishima, Noriaki Mitsuda, Jun Nakura, Kouzin Kamino, \\ Naoyuki Sato, Tetsuro Miki and Toshio Ogihara
}

Werner syndrome (WRN) is a rare autosomal recessive disorder, one of the progeroid syndromes, and is characterized by features of premature aging. The incidence of WRN in the Japanese population, 1 in 200,000, is higher than than that in the Caucasian population. The genetic defect of WRN is unknown. But genetic linkage to several markers on the short arm of chromosome 8 has been reported recently. Here, we studied one family with WRN in which an affected individual had a papillary thyroid carcinoma and myelodysplastic syndrome. Using 4 microsatellites closely located to the WRN locus:

Department of Geriatric Medicine, Osaka University Medical School
D8S360, D8S1055, D8S339 and ANK1, we analyzed the genotypes of this patient, her three siblings and her parents, who were first cousins. The mutative haplotype, identified through the generations in pedigree, helps detect a carrier or a presymptomatic patient. The eldest sister inherited two normal haplotypes, but the second sister inherited one mutative haplotype. There was no difference in clinical signs and symptoms between these sisters. when the WRN gene is isolated, it will help us understand the mechanism of aging.

Key words: Werner syndrome, Polymorphic microsatellite, Genetic analysis, Homozygosity mapping (Jpn J Geriat 1995; 32: 817-821.) 